\title{
STRATEGI PENGENTASAN KEMISKINAN PADA PERTANIAN LAHAN KERING DI JAWA BARAT
}

Poverty Alleviation Strategies in Dryland Agriculture in West Java

\author{
Yusman Syaukat ${ }^{1}$, A Faroby Falatehan ${ }^{1}$, Nizar Nasrullah ${ }^{2}$, Arini Hardjanto ${ }^{1}$
}
1Staf Pengajar Departemen Ekonomi Sumberdaya dan Lingkungan. Fakultas Ekonomi dan Manajemen. IPB. Email: ysyaukat@gmail.com, affalatehan@gmail.com, 2Staf Pengajar Departemen DepartemenArsitektur Lanskap. Fakultas Pertanian. IPB. Email: nizarnasrullah@yahoo.com

\begin{abstract}
Majority of the community in Sukabumi and Tasikmalaya Districts are still below the poverty line. The approach used to analyze poverty levels is an expenditure approach which is then compared to the poverty limit of the BKKBN and BPS. Communities in Sukabumi and Tasikmalaya District are classified to the first prosperous family (KS1) based on the classification of the BKKBN. Whereas compared to BPS poverty level, Communities in Sukabumi District are classified as poor that is 15.79 percent and 19.23 percent for Tasikmalaya District. The second objective of this study was to implement a cropping strategy that farmers should do to increase farmers' income so that they are not below the poverty line. The recommended cropping pattern is by planting horticultural crops such as spinach, caisin, watermelon and melon in the third growing season.
\end{abstract}

Keywords: poverty, dry land, farming, food

\begin{abstract}
ABSTRAK
Kabupaten Sukabumi dan Tasikmalaya yang menjadi daerah penelitian ini masih terdapat masyarakat yang berada di bawah garis kemiskinan. Pendekatan yang digunakan untuk menganalisis tingkat kemiskinan menggunakan pendekatan pengeluaran yang kemudian dibandingkan dengan batas kemiskinan dari BKKBN dan BPS. Masyarakat di Kabupaten Sukabumi dan Tasikmalaya berada pada golongan keluarga sejahtera I berdasarkan penggolongan dari BKKBN. Sedangkan bila dibandingkan berdasarkan tingkat kemiskinan BPS, masyarakat Kabupaten Sukabumi yang tergolong miskin sebanyak 15.79 persen dan pada Kabupaten Tasikmalaya sebanyak 19.23 persen. Tujuan kedua dari penelitian ini adalah strategi pola tanam yang sebaiknya dilakukan petani untuk meningkatkan pendapatan petani agar tidak berada dibawah garis kemiskinan. Pola tanam yang disarankan yaitu menanam tanaman hortikultura seperti kangkung darat, caisin/sawi, semangka dan melon pada musim tanam ketiga.
\end{abstract}

Kata kunci: kemiskinan, lahan kering, usahatani, pangan

\section{PENDAHULUAN}

Kemiskinan merupakan fenomena yang umum ditemui di negara-negara berkembang, termasuk Indonesia. Kemiskinan menjadi salah satu fokus utama dari proses pembangunan ekonomi karena mengggambarkan tercapainya unsur pemerataan (equity) yang merupakan indikator dari kemakmuran. Sebagian besar masyarakat miskin di
Indonesia tinggal di wilayah pedesaan karena tidak mampu bersaing dengan tenaga kerja terdidik dan mencari pekerjaan di perkotaan. Berdasarkan data BPS (2016), lebih dari separuh rumahtangga miskin memperoleh penghasilann utamanya dari sektor pertanian, sementara sebagian besar lainnya bekerja pada sektor industri dan lainnya. 
Pertanian lahan kering didefinisikan sebagai pertanian pada lahan yang tidak memiliki fasilitas pengairan (FAO, 2012). Usaha pertanian yang umum diusahakan pada lahan kering adalah tanaman pangan, hortikultura dan peternakan. Karena tidak memiliki fasilitas pengairan, sumber air bagi pertanian di lahan kering adalah air hujan. Sementara, untuk daerah-daerah dengan jumlah lahan kering yang tinggi di Indonesia (Jawa Timur, Sulawesi, Bali, NTB dan NTT), curah hujan yang terjadi tidaklah tinggi. Hal ini membuat pengusahaan pertanian pada lahan kering seringkali tidak diminati oleh petani dan hanya sebagian kecil saja yang mengusahakannya secara komersial. Sebagian besar petani masih bertani di lahan kering sebatas untuk memenuhi kebutuhan pangan rumahtangganya saja sehingga seringkali tidak ada keseragaman pola tanam pada pertanian di lahan kering. Padahal, lahan kering sangat berpotensi menghasilkan berbagai variasi produk pangan, yakni padi gogo, jagung, kedelai, shorgum, dan ubi-ubian (Abdurachman et al, 2008).

Data BPS menyatakan bahwa Propinsi Jawa Barat juga menempati posisi ketiga untuk jumlah penduduk miskin setelah Propinsi Jawa Timur dan Jawa Tengah. Pada bulan September 2014, sebanyak $15 \%$ dari penduduk miskin di Indonesia tinggal di propinsi Jawa Barat. Sebagian besar dari penduduk miskin ini berada di wilayah Kabupaten Bogor, Garut dan Cirebon. Namun jika dibagi menurut wilayah, daerah bagian selatan memiliki lebih dari setengah jumlah penduduk miskin di Jawa Barat. Tidak hanya kemiskinan, besarnya kontribusi Jawa Barat pada sektor pertanian juga tidak menjamin kebutuhan pangan daerah-daerah di Jawa Barat dapat dipenuhi secara mandiri. Dari 28 kabupaten/kota di Provinsi Jawa Barat, masih ada beberapa wilayah yang berstatus rawan pangan karena tidak dapat memenuhi kebutuhan pangannya sendiri sehingga harus membeli dari daerah lainnya (Priyambodo, 2015). Hal tersebut mengindikasikan masih perlunya upaya peningkatan produksi pertanian di wilayah Jawa Barat.

Potensi pengembangan sektor pertanian di wilayah Jawa Barat relatif lebih besar dibandingkan wilayah lain karena lokasinya yang strategis dan iklimnya yang cukup baik. Sebagai daerah yang berpotensi besar dalam pengembangan produksi pertaniannya, nyatanya selama ini masih banyak lahan yang belum dapat dimanfaatkan dengan maksimal. Dari karakteristik wilayah, terdapat perbedaan kondisi antara Jawa Barat bagian utara dan selatan. Berbeda dengan kondisi tanah bagian utara yang dikenal subur, kondisi tanah di Jawa Barat bagian selatan didominasi oleh lahan kering. Lahan kering di wilayah bagian selatan merupakan yang terbesar diantara dua wilayah lainnya yang ada di Jawa Barat yaitu bagian utara dan tengah. Luas lahan kering di wilayah selatan mencapai 55.98 persen dari total lahan kering yang ada di Jawa Barat. Kabupaten Sukabumi adalah daerah yang memiliki luas lahan kering terbesar di wilayah selatan yaitu sebesar 232.023 ha, disusul oleh Kabupaten Tasikmalaya (Rachmat, 2013). Luasnya lahan kering yang dimiliki oleh wilayah Jawa Barat Selatan tidak didukung oleh sistem pengairan yang baik. Hal ini disebabkan besar lahan pertanian di wilayah selatan berada diatas aliran sungai sehingga saluran irigasi sulit untuk dibuat. Sehingga, ketersediaan air pada kawasan ini sangat bergantung pada curah hujan.

Lahan kering memiliki potensi yang cukup besar dalam upaya peningkatan produksi pertanian di Kabupaten Sukabumi dan Tasikmalaya. Namun, selama ini pemanfaatan lahan kering dalam usahatani komersil masih belum dilakukan secara maksimal sehingga masih banyak lahan kering yang menganggur. Secara umum, belum ada komoditas unggulan bernilai ekonomis tinggi yang dihasilkan dari zona agrosistem yang sangat bergantung pada curah hujan ini. Secara demografis, 
sebagian besar petani yang berada pada zona agrosistem ini memiliki lahan yang sempit, bermodal kecil, serta masih menganut sistem pertanian subsisten (Setiawan, 2008).

Lahan kering yang ditanami tanaman padi di Kabupaten Sukabumi sebagian besar berupa sawah tadah hujan, dengan pola tanam padi 1-2 kali dalam satu tahun. Tanaman lain yang ditanam selain padi berupa tanaman palawija seperti kacang kedelai, cabai, ubi, dan jagung. Produktivitas padi pada MT 1 sebesar 7, ton/Ha, produktivitas yang tinggi ini dikarenakan padi ditanam pada saat musim penghujan sehingga cukup air. Di Kabupaten Tasikmalaya, lahan kering yang ditanami tanaman padi sebagian besar berupa ladang dan sawah tadah hujan, dengan pola tanam padi 1-2 kali dalam satu tahun. Produktivitas padi pada MT 1 hanya sebesar 3, ton/Ha, nilai produktivitas yang rendah terjadi karena pada musim tanam tersebut petani mengalami gagal panen, meskipun belum diketahui penyebab gagal panen tersebut (Falatehan et al 2017).

Berdasarkan permasalahan, dapat diformulasikan tujuan umum dari penelitian ini yaitu ingin mengoptimalkan pemanfaatan lahan kering di Kabupaten Sukabumi dan Tasikmalaya dan merumuskan kebijakan dalam upaya peningkatan kesejahteraan masyarakat. Secara khusus tujuan dari penelitian ini adalah untuk: (1) menganalisis tingkat kemiskinan petani lahan kering di Kabupaten Sukabumi dan Tasikmalaya pada saat ini; (2) merumuskan strategi pola tanam dan produksi yang optimal di lahan kering Kabupaten Sukabumi dan Tasikmalaya upaya memenuhi kebutuhan pangan dan menurunkan tingkat kemiskinan.

\section{METODOLOGI}

\section{Lokasi Penelitian}

Lokasi survei berada di dua lokasi dengan luas lahan kering tertinggi di wilayah Jawa Barat Selatan, yaitu di Kabupaten Sukabumi dan Kabupaten Tasikmalaya. Kegiatan pendampingan teknis budidaya dan pemasaran terkait kajian dilaksanakan di Kecamatan Surade Kabupaten Sukabumi dan Kecamatan Cipatujah Kabupaten Tasikmalaya.

\section{Jenis dan Sumber Data}

Data yang digunakan dalam penelitian ini berupa data primer dan data sekunder. Data primer diperoleh langsung di lapangan dengan cara survei, in depth interview, pengisian kuesioner, dan Focus Group Discussion (FGD). Sumber data sekunder diperoleh dari Badan Pusat Statistik (BPS), Kementerian Pertanian, Badan Perencanaan Pembangunan Nasional (Bappenas), Badan Meteorologi Klimatologi dan Geofisika (BMKG), Dinas Pertanian Propinsi Jawa Barat, institusi nasional dan internasional, serta berbagai sumber lainnya yang berasal dari penelitian sebelumnya.

\section{Metode Pengambilan Sampel}

Pengambilan sampel yang digunakan adalah nonprobability sampling dengan metode purposive sampling. Pengambilan sampel diperlukan untuk mengidentifikasi tingkat kemiskinan, strategi pola tanam dan produksi yang optimal di lahan kering Kabupaten Sukabumi dan Kabupaten Tasikmalaya. Pengambilan sampel digunakan juga untuk menentukan lokasi pendampingan implementasi alternatif kegiatan optimasi produksi pangan di lahan kering Kabupaten Sukabumi dan Tasikmalaya dalam upaya memenuhi kebutuhan pangan dan menurunkan tingkat kemiskinan.

\section{Metode Analisis}

\section{1) Analisis Tingkat Kemiskinan}

Tingkat kemiskinan petani lahan kering di Kabupaten Sukabumi dan Kabupaten Tasikmalaya dianalisis melalui pendekatan pengeluaran yang kemudian kategorikan ke dalam kriteria dan garis kemiskinan. Terdapat beberapa acuan garis kemiskinan. Di Indonesia, garis 
kemiskinan didekati dari data BPS. Tingkat kemiskinan petani lahan kering dianalisis dengan membandingkan tingkat pengeluaran per kapita per bulan lahan kering dengan garis kemiskinan menurut Provinsi berdasarkan Badan Pusat Statistik (BPS).

\section{2) Analisis Data Agroklimat}

Analisis data agroklimat digunakan untuk memilih pola tanam yang menghasilkan tingkat produksi optimum. Teori pemilihan komoditas yang dapat menghasilkan tingkat produksi optimum dianalisis dengan memperhatikan kesesuaian iklim, curah hujan, kondisi tanah, kondisi air, serta hama dan penyakit yang biasa terdapat pada usahatani di lahan kering Kabupaten Sukabumi dan Kabupaten Tasikmalaya. Berdasarkan data agroklimat yang terdapat di wilayah usahatani lahan kering Kabupaten Sukabumi dan Kabupaten Tasikmalaya dapat dilihat tanaman yang sesuai untuk ditanam di lahan kering tersebut.

\section{HASIL DAN PEMBAHASAN}

\section{a. Tingkat kemiskinan di Sukabumi dan Tasikmalaya berdasarkan BKKBN}

Badan Kependudukan dan Keluarga Berencana Nasional (BKKBN) menetapkan kemiskinan berdasarkan pendekatan keluarga yang membagi kriteria keluarga dalam lima tahapan yaitu keluarga prasejahtera (KPS), keluarga sejahtera I (KS- I), keluarga sejahtera II (KS-II), keluarga sejahtera III (KS-III), dan keluarga sejahtera III plus (KS-III Plus). Aspek keluarga sejahtera dikumpulkan dengan menggunakan 21 indikator sesuai dengan pemikiran para pakar sosiologi dalam membangun keluarga sejahtera dengan mengetahui faktor-faktor dominan yang menjadi kebutuhan setiap keluarga. Faktor - faktor dominan tersebut terdiri dari (1) pemenuhan kebutuhan dasar; (2) pemenuhan kebutuhan psikologi; (3) kebutuhan pengembangan; dan (4) kebutuhan aktualisasi diri dalam berkontribusi bagi masyarakat di lingkungannya. Berdasarkan Badan Kependudukan dan Keluarga Berencana Nasional, tingkat kesejahteraan keluarga dikelompokkan menjadi 5 (lima) tahapan, yaitu:

\section{Tahapan Keluarga Pra Sejahtera (KPS)}

Yaitu keluarga yang tidak memenuhi salah satu dari 6 (enam) indikator Keluarga Sejahtera I (KS I) atau indikator "kebutuhan dasar keluarga" (basic needs).

2. Tahapan Keluarga Sejahtera I (KSI) Yaitu keluarga mampu memenuhi 6 (enam) indikator tahapan KS I, tetapi tidak memenuhi salah satu dari 8 (delapan) indikator Keluarga Sejahtera II atau indikator "kebutuhan psikologis" (psychological needs) keluarga.

\section{Tahapan Keluarga Sejahtera II}

Yaitu keluarga yang mampu memenuhi 6 (enam) indikator tahapan KS I dan 8 (delapan) indikator KS II, tetapi tidak memenuhi salah satu dari 5 (lima) indikator Keluarga Sejahtera III (KS III), atau indikator "kebutuhan pengembangan" (develomental needs) dari keluarga.

\section{Tahapan Keluarga Sejahtera III}

Yaitu keluarga yang mampu memenuhi 6 (enam) indikator tahapan KS I, 8 (delapan) indikator KS II, dan 5 (lima) indikator KS III, tetapi tidak memenuhi salah satu dari 2 (dua) indikator Keluarga Sejahtera III Plus (KS III Plus) atau indikator "aktualisasi diri" (self esteem) keluarga.

\section{Tahapan Keluarga Sejahtera III Plus}

Yaitu keluarga yang mampu memenuhi keseluruhan dari 6 (enam) indikator tahapan KS I, 8 (delapan) indikator KS II, 5 (lima) indikator KS III, serta 2 (dua) indikator tahapan KS III Plus.

Penelitian ini bermaksud melihat apakah petani di daerah penelitian tergolong dalam kelompok keluarga miskin (pra-sejahtera) atau tidak. Oleh karena itu, paling tidak responden harus memenuhi salah satu dari indikator Keluarga Sejahtera I. Enam Indikator tahapan Keluarga Sejahtera I (KS I) atau 
indikator "kebutuhan dasar keluarga" (basic needs), dari 21 indikator keluarga sejahtera yaitu:

\section{Pada umumnya anggota keluarga makan dua kali sehari atau lebih.}

Pengertian makan adalah makan menurut pengertian dan kebiasaan masyarakat setempat, seperti makan nasi bagi mereka yang biasa makan nasi sebagai makanan pokoknya (staple food), atau seperti makan sagu bagi mereka yang biasa makan sagu dan sebagainya.

\section{Anggota keluarga memiliki} pakaian yang berbeda untuk di rumah, bekerja/sekolah dan bepergian.

Pengertian pakaian yang berbeda adalah pemilikan pakaian yang tidak hanya satu pasang, sehingga tidak terpaksa harus memakai pakaian yang sama dalam kegiatan hidup yang berbeda beda. Misalnya pakaian untuk di rumah (untuk tidur atau beristirahat di rumah) lain dengan pakaian untuk ke sekolah atau untuk bekerja (ke sawah, ke kantor, berjualan dan sebagainya) dan lain pula dengan pakaian untuk bepergian (seperti menghadiri undangan perkawinan, piknik, ke rumah ibadah dan sebagainya).

\section{Rumah yang ditempati keluarga mempunyai atap, lantai dan dinding yang baik.}

Pengertian Rumah yang ditempati keluarga ini adalah keadaan rumah tinggal keluarga mempunyai atap, lantai dan dinding dalam kondisi yang layak ditempati, baik dari segi perlindungan maupun dari segi kesehatan.

\section{Bila ada anggota keluarga sakit dibawa ke sarana kesehatan.}

Pengertian sarana kesehatan adalah sarana kesehatan modern, seperti Rumah Sakit, Puskesmas, Puskesmas Pembantu, Balai Pengobatan, Apotek, Posyandu, Poliklinik, Bidan Desa dan sebagainya, yang memberikan obat obatan yang diproduksi secara modern dan telah mendapat izin peredaran dari instansi yang berwenang (Departemen Kesehatan/ Badan POM).

\section{Bila pasangan usia subur ingin ber} KB pergi ke sarana pelayanan kontrasepsi.

Pengertian Sarana Pelayanan Kontrasepsi adalah sarana atau tempat pelayanan KB, seperti Rumah Sakit, Puskesmas, Puskesmas Pembantu, Balai Pengobatan, Apotek, Posyandu, Poliklinik, Dokter Swasta, Bidan Desa dan sebagainya, yang memberikan pelayanan $\mathrm{KB}$ dengan alat kontrasepsi modern, seperti IUD, MOW, MOP, Kondom, Implan, Suntikan dan Pil, kepada pasangan usia subur yang membutuhkan. (Hanya untuk keluarga yang berstatus Pasangan Usia Subur).

\section{Semua anak umur 7-15 tahun dalam keluarga bersekolah.}

Pengertian Semua anak umur 7-15 tahun adalah semua anak 7-15 tahun dari keluarga (jika keluarga mempunyai anak 7-15 tahun), yang harus mengikuti wajib belajar 9 tahun. Bersekolah diartikan anak usia 7-15 tahun di keluarga itu terdaftar dan aktif bersekolah setingkat $\mathrm{SD} /$ sederajat SD atau setingkat SLTP/sederajat SLTP.

Penelitian ini membahas lima buah indikator Keluarga Sejahtera I yaitu indikator nomor 1,2,3,4, dan 6. Pada penelitian ini ada satu indikator Keluarga Sejahtera I yang tidak dibahas yaitu indikator kelima (Bila pasangan usia subur ingin ber KB pergi ke sarana pelayanan kontrasepsi).

Dari lima indikator yang dibahas, terdapat tiga indikator dimana seluruh responden baik responden di Kabupaten Sukabumi maupun responden di Kabupaten Tasikmalaya telah memenuhi ketiga indikator tersebut. Indikator tersebut adalah indikator 2,4 dan 6 yaitu anggota keluarga memiliki pakaian yang berbeda untuk di rumah, bekerja/sekolah dan bepergian, bila ada anggota keluarga sakit dibawa ke sarana kesehatan dan semua 
anak umur 7-15 tahun dalam keluarga bersekolah. Sementara itu untuk dua indikator lainnya, tidak semua responden dapat memenuhi indikator tersebut.

Pada indikator 1 yaitu "pada umumnya anggota keluarga makan dua kali sehari atau lebih", terdapat beberapa responden yang tidak dapat memenuhinya. Pada Kabupaten Tasikmalaya terdapat empat orang dan pada Kabupaten Sukabumi terdapat tiga orang petani responden yang tidak memiliki kemampuan untuk memenuhi kebutuhan makan keluarganya lebih dari satu kali per hari. Hal ini direfleksikan kepada rendahnya besaran pengeluaran untuk makanan dari ketujuh petani responden tersebut.

Pada indikator "rumah yang ditempati keluarga mempunyai atap, lantai dan dinding yang baik" terdapat beberapa responden yang belum bisa memenuhi kebutuhan rumahnya dengan baik. Keadaan rumah tinggal keluarga seharusnya mempunyai atap, lantai dan dinding dalam kondisi yang layak ditempati, baik dari segi perlindungan maupun dari segi kesehatan. Pada Kabupaten Tasikmalaya dan Kabupaten Sukabumi, terdapat masing-masing dua orang petani responden yang tidak memiliki rumah tinggal yang layak. Rumah dari keempat responden tersebut masih berupa rumah dengan dinding bambu dan lantai kayu. Sehingga dari segi perlindungan dan kesehatan masih kurang layak untuk ditempati.

Dari standar yang ditetapkan BKKBN, maka jika ada salah satu dari indikator keluarga sejahtera I yang tidak dipenuhi, maka keluarga/rumah tangga tersebut tergolong ke dalam kelompok keluarga pra-sejahtera. Dari 26 responden di Kabupaten Tasikmalaya, terdapat enam orang petani responden yang dapat dinyatakan sebagai keluarga pra sejahtera. Diantara enam orang ini, empat orang responden belum dapat memenuhi kebutuhan pangan hariannya dan dua orang responden belum dapat memenuhi kondisi rumah tempat tinggal yang layak.
Sementara itu dari 19 orang responden di Kabupaten Sukabumi, empat orang responden dapat digolongkan ke dalam keluarga pra sejahtera. Dari keempat orang ini, sebanyak dua orang responden belum mampu memenuhi kebutuhan pangan hariannya, satu orang belum mampu memenuhi kondisi rumah tempat tinggal yang layak dan satu orang lagi belum mampu memenuhi kedua kebutuhan tersebut.

\section{b. Tingkat Kemiskinan di Kabupaten Sukabumi dan Tasikmalaya berdasarkan Garis Kemiskinan BPS}

Garis kemiskinan Provinsi Jawa Barat masih berada di bawah garis kemiskinan nasional. Garis kemiskinan nasional berdasarkan data BPS (2017) pada tahun 2017 adalah sebesar Rp. 366.203 per kapita per bulan, sementara garis kemiskinan Provinsi Jawa Barat adalah sebesar Rp. 344.472 per kapita per bulan. Besaran nilai garis kemiskinan ini telah mengalami kenaikan dari tahuntahun sebelumnya.

Tingkat garis kemiskinan di kabupaten/kota di Provinsi Jawa Barat pada tahun 2017 menunjukkan bahwa garis kemiskinan Kabupaten Tasikmalaya dan Kabupaten Sukabumi berturut-turut adalah sebesar Rp. 284.462 dan Rp. 284.603 per kapita per bulan. Garis kemiskinan Kabupaten Sukabumi dan Tasikmalaya ini merupakan garis kemiskinan terendah kedua dan ketiga di Provinsi Jawa Barat setelah Kabupaten Garut. Hal ini dapat disebabkan oleh rendahnya rata-rata konsumsi penduduk di daerah tersebut.

Berdasarkan data BPS (2017), Provinsi Jawa Barat merupakan provinsi dengan jumlah penduduk miskin terbesar di Indonesia. Sebagian besar penduduk miskin di Provinsi Jawa Barat berada pada kawasan pedesaan $(61,2 \%)$ dibandingkan kawasan perkotaan (38,8\%). Jika dibandingkan dengan kabupaten/kota lainnya, Kabupaten Sukabumi dan Kabupaten Tasikmalaya menempati urutan ke-7 dan ke-10, dimana urutan 
pertama adalah Kabupaten Bogor dengan jumlah penduduk miskin mencapai 487,28 ribu orang selama tahun 2017. Meskipun demikian, jumlah penduduk miskin di Kabupaten Sukabumi dan Kabupaten Tasikmalaya senantiasa mengalami penurunan dari tahun ke tahun. Kabupaten Sukabumi dan Kabupaten Tasikmalaya masing-masing menyumbang 4,7 persen dan 4,5 persen dari total penduduk miskin di Provinsi Jawa Barat.

Penduduk miskin yang berada di Kabupaten Sukabumi berdasarkan hasil survei penelitian hanya sebesar 15.79 persen. Sebagian besar penduduk di Kabupaten Sukabumi tergolong penduduk tidak miskin berdasarkan hasil survei lapang yaitu sebanyak 16 orang (84.21 persen). Penggolongan penduduk miskin ini didekati dari pengeluaran responden baik makanan maupun non makanan. Garis kemiskinan Kabupaten Sukabumi berdasarkan BPS sebesar Rp 284,063 per kapita per bulan. Rata-rata pengeluaran per kapita per bulan di Kabupaten Sukabumi sebesar Rp 455,154. Pengeluaran terbesar per kapita per bulan dari jumlah responden yang diwawancara sebesar Rp 2,220,000 dan pengeluaran terkecil sebesar Rp 168,333. Sumber pengeluaran terbesar berasal dari makanan, pendidikan, dan kebutuhan barang rumahtangga lainnya seperti sabun dan lain-lain. Persentase pengeluaran dari komponen makanan sebesar 48.07 persen, pendidikan sebesar 18.23 persen dan kebutuhan barang lainnya sebesar 11.86 persen.

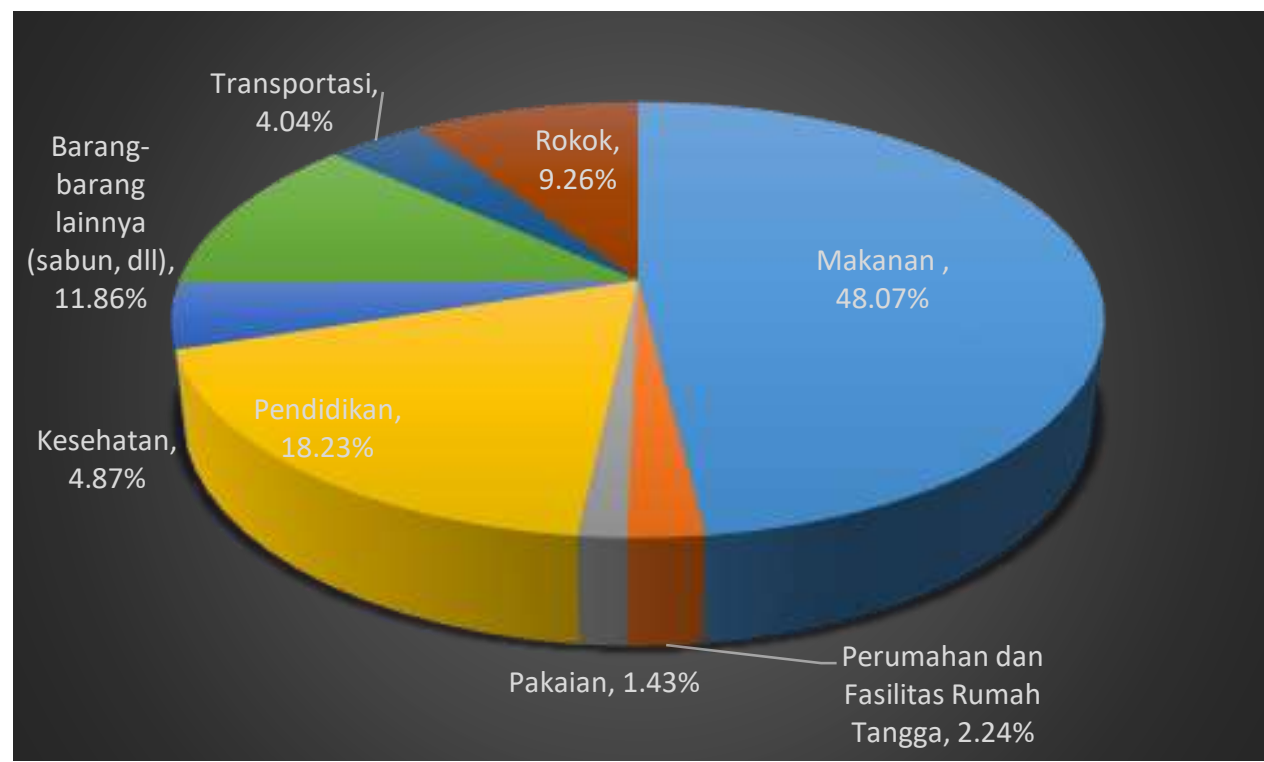

\section{Gambar 1 Pengeluaran Rumah Tangga Petani di Kecamatan Surade, Kabupaten Sukabumi}

Kemiskinan di Kabupaten Sukabumi dapat dikurangi melalui sektor pertanian. Cara yang dapat ditempuh dengan meningkatkan produktivitas pertanian dengan menggunakan teknologi modern sehingga rumahtangga miskin dapat keluar dari kemiskinan. Cara kedua yang dapat ditempuh untuk mengatasi kemiskinan dengan revitalisasi pertanian dengan pengelolaan irigasi yang baik. Selanjutnya yang dapat dilakukan untuk mengurangi kemiskinan dengan diversifikasi jenis tanaman yang memiliki nilai lebih tinggi dibandingkan dengan tanaman yang biasa ditanam seperti tanaman hortikultura, perikanan dan peternakan. Akan tetapi dalam pengaplikasiannya, petani harus dapat didampingi oleh penyuluh atau tenaga ahli, sehingga diversifikasi tanaman dapat berjalan dengan maksimal.

Seperti halnya Kabupaten Sukabumi, jumlah penduduk miskin di Kabupaten Tasikmalaya berdasarkan hasil penelitian tidak berbeda jauh dengan Kabupaten Sukabumi yaitu sebesar 19.23 persen. Garis kemiskinan Kabupaten Tasikmalaya berdasarkan BPS 
sebesar Rp 284,462 per kapita per bulan. Pengeluaran terbesar berasal dari makanan yaitu 50,93 persen, pengeluaran kedua terbesar yaitu rokok (14.56 persen), pengeluaran ketiga terbesar adalah pendidikan yaitu 12.63 persen. Rokok menjadi pengeluaran kedua terbesar setelah makanan, hasil ini sesuai dengan hasil Survei Sosial Ekonomi Nasional (Susenas) 2015 yang menjadikan rokok sebagai pengeluaran terbesar mengalahkan beras. Konsumsi rokok di Indonesia cenderung meningkat setiap tahunnya karena pemerintah Indonesia belum optimal dalam mengendalikan rokok (Lembaga Demografi UI, 2012) dan harga rokok di Indonesia relatif murah dibandingkan negara-negara maju lainnya.

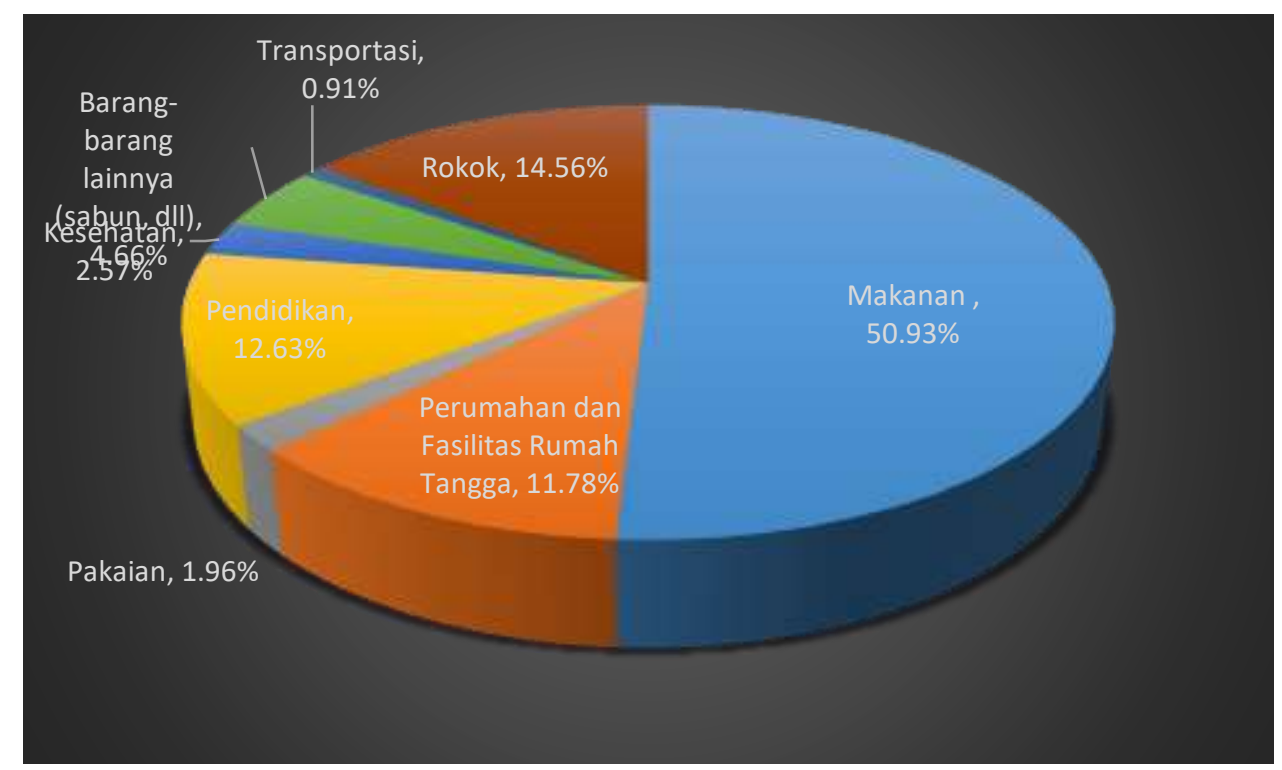

\section{Gambar 2 Pengeluaran Rumah Tangga Petani di Kecamatan Cipatujah, Kabupaten Tasikmalaya}

Pendidikan telah menjadi salah satu pengeluaran terbesar baik di Kabupaten Sukabumi maupun Tasikmalaya, namun bidang kesehatan belum menjadi pengeluaran terbesar, sehingga perlu ditingkatkan pentingnya peran kesehatan bagi masyarakat. Salah satu cara untuk mennaggulangi kemiskinan adalah dengan memperhatikan sektor kesehatan melalui investasi kesehatan. Bentuk investasi kesehatan seperti peningkatan kualitas pelayanan kesehatan dasar dan peningkatan akses pemeliharaan kesehatan. Kebijakan lain yang dapat mengurangi tingkat kemiskinan berupa proyek pembangunan nasional yang dilakukan oleh dan untuk masyarakat. Proyek yang melibatkan masyarakat telah terbukti efektif dapat berjalan dengan baik dan pengembalian investasi relatif tinggi. Keuntungan dari proyek berbasis masyarakat adalah dapat memberdayakan masyarakat miskin dan memiliki dampak yang baik bagi pembangunan wilayahnya.

\section{Alternatif Strategi Pengentasan Kemiskinan}

Alternatif tanaman yang dapat ditanam, selain itu petani diberikan informasi cara menanam tanaman yang baik melalui pembuatan demplot. Beberapa komoditas yang dipilih, yaitu semangka, melon, sawi dan kangkung. Keempat komoditas ini disarankan kepada para petani karena sebagian besar petani di kedua kecamatan belum pernah menanam komoditas-komoditas ini. Padahal jika dilihat dari kesesuaian tanaman-tanaman tersebut jika di tanam di lahan kering sangat sesuai.

Sementara itu jika dilihat secara finansial, tanaman-tanaman ini memiliki nilai ekonomis yang tinggi, seperti untuk sayuran yang dapat dipanen setiap dua minggu. 
Tabel 1 Alternatif Pola Tanam untuk Kecamatan Sukabumi dan Tasikmalaya

\begin{tabular}{|c|c|c|}
\hline $\begin{array}{c}\text { Musim } \\
\text { Tanam } \\
\text { I }\end{array}$ & $\begin{array}{c}\text { Musim } \\
\text { Tanam II }\end{array}$ & Musim Tanam III \\
\hline Padi & Padi & $\begin{array}{c}\text { Melon, Semangka, } \\
\text { Sawi Atau } \\
\text { Kangkung }\end{array}$ \\
\hline
\end{tabular}

\section{SIMPULAN}

Kemiskinan yang berada Kabupaten Sukabumi dan Tasikmalaya didekati dengan pendekatan BKKBN dan BPS. Hasil yang diperoleh bahwa sebagian besar masyarakat di dua Kabupaten merupakan golongan keluarga sejahtera I. Apabila dilihat dari pendekatan pengeluaran, maka hanya 15 persen di Kabupaten Sukabumi dan 11.56 persen di Kabupaten Tasikmalaya yang tergolong kedalam penduduk miskin yang dibandingkan dengan garis kemiskinan menurut BPS.

Strategi pengentasan kemiskinan di kawasan ini adalah melalui peningkatan penanaman, terutama pada musim tanam III. Biasanya pada musim ketiga petani tidak menanam tanaman apapun atau dalam lahan dalam kondisi bera, akan tetapi untuk meningkatkan pendapatan petani maka pada musim ketiga petani disarankan untuk menanam tanaman hortikultura, seperti kangkung darat, caisin, semangka, dan melon.

\section{DAFTAR PUSTAKA}

Falatehan AF, Syaukat Y, Reswatie FD, Sari DAP. Planting and Consumption Patterns of Upland Rice Farmer in Indonesia. ADRI International Journal of Agriculture Volume 1 No 12017 Isdijoso W, Suryahadi A, Akhmadi. 2016.

Penetapan Kriteria dan Variabel Pendataan Penduduk Miskin yang Komprehensif dalam Rangka
Perlindungan Penduduk Miskin di Kabupaten/Kota. The SMERU Research Institute.

Kementrian Ristek. 2000. Budidaya Semangka. Jakarta

Priyambodo RH. (2015). Deddy Mizwar: Empat daerah di Jabar rawan pangan.

http://www.antaranews.com [diakses 3 mei 2016]

Nurwati, N. 2008. Kemiskinan: Model Pengukuran, Permasalahan dan Alternatif Kebijakan. Jurnal Kependudukan Padjajaran 10 (1): 1-11.

Supriatna. 1997. Kemiskinan : Teori, Fakta dan kebijakan, impac Edisi

Todaro, Michael P. dan Stephen C. Smith. 2006. Pembangunan Ekonomi (edisi kesembilan, jilid I). Jakarta : Erlangga

Soekartawi. 1995. AnalisisUsahatani. Universitas Indonesia Press. Jakarta.

Suwarno, B. Kustianto, WS Arjasa and GN Atlin. 2002. Participatory selection on upland rice in Sumatra. Breeding rainfed for drought-rpone environment: integrating conventional and participatory plant breeding in South and Southeast Asia. Proceeding of DFID Plant Sciences Research Programme/IRRI Conference. 1215 March 2002. Los Banos 